\title{
Application of Tasselled-Cap Transformation to Soil Textural Mapping of a Semi-Arid Environment: A Case of Usmanu Danfodiyo University Main Campus, Sokoto, Nigeria
}

\author{
Eniolorunda N. B.* and Jibrillah A. M. \\ Department of Geography, Faculty of Social Sciences, Usmanu Danfodiyo University, Sokoto, Nigeria \\ Corresponding Author: *nathaniel.bayode@ udusok.edu.ng
}

https://doi.org/10.36263/nijest.2020.01.0158

\begin{abstract}
Information on soil attributes still largely relies on traditional methods of point sampling and subsequent laboratory test which are time and resource consuming. Thus, this study tested the applicability of Kauth-Thomas Tasseled-Cap Transformation (TCT) to soil textural mapping on the main campus of Usmanu Danfodiyo University, Sokoto as a faster method. The study hypothesized that the TCT-Brightness image had no relationship individually with soil particle size and Land use/ Land Cover (LUC). Landsat 8 of 22-03-2019 was preprocessed with QGIS and subjected to TCT in Idrisi Terrset to produce the TCT-Brightness image. Soil samples were collected at 91 points based on stratified random sampling at $0-15 \mathrm{~cm}$ depth. Soil particle size was determined by Bouyoucos Hydrometer method. Simple linear regression analysis was used to model soil particle sizes from the TCT-Brightness image, while soil textural map was produced in SAGA. LUC of the area was mapped at Level III within the Google Earth Engine (GEE). Cross map-tabulation was carried out to test for the relationship between LUC and soil texture. Four textural classes were obtained namely sandy-clay-loam, loamy sand, sand and sandy-loam, with sand being dominant. Soil particle sizes were modeled at $99.85 \%$ accuracy, while soil textural mapping yielded 95\% accuracy. Five LUC classes namely: built-up area, wetland, upland forest, bare surface and riparian forest, were mapped at $98.3 \%$ accuracy, with bare surface being dominant. A significant $(p<0.01)$ relationship between LUC and soil texture was obtained at 0.85 Kappa Index of Agreement. The study concluded that the TCT is sufficient for predicting soil texture in a largely sandy semi-arid environment. A repeat of this study for the wet season was recommended.
\end{abstract}

Keywords: Soil Texture, Tasseled Cap Transformation, Soil Brightness Image, Landsat, Kappa

\subsection{Introduction}

The coupling of anthropogenic pressure and climate change on the landscape in the $21^{\text {st }}$ century has necessitated good and sustainable soil management which is critical to successful agriculture (Zribi et al., 2011). Understanding soil attributes and types within an area in a short time will be critical to making best land-use decisions as changes in landscape are expected to accelerate with time (Menezes et al., 2014; Silva et al., 2014). Thus, information on soil must be timely and of high fidelity for quick decision making. Besides agriculture, soil information is needed for policy-making, land resource management, and monitoring of the environmental impact of development projects (Mulder et al., 2011). The traditional way of getting soil data in most countries of the world requires recurrence of point sampling and subsequent laboratory determination of both the physical and chemical properties. This procedure is time and resource consuming especially where information is needed urgently and resources are limited.

The need for crop production maximization and sustainable use of agricultural land in the face of growing population calls for smart methods of soil data collection and analysis. In the last four decades, there has been great interest in the development of inexpensive and rapid soil mapping methods, and remote sensing of soil is particularly valuable and handy to fill the gap (Casa et al., 2013). The reflected or emitted radiation by soil varies according to a range of chemical and physical 
characteristics of the soil matrix which makes it possible for discrimination between different soil surfaces across different wavelengths or a combination of spectral bands (Dewitte et al., 2012).

Remote sensing of surface soil properties with space borne or airborne approaches dates back to 1980s, and today, several methods of image processing have been used to extrapolate soil data (Hartemink and Minasny, 2014). Although optical remote sensing can penetrate only few centimeters into the ground, it has been suitably used for mapping soil mineralogy, texture, soil iron, soil moisture, soil organic carbon, soil salinity and carbonate content (Hartemink and Minasny, 2014).

In Nigeria, most remote sensing studies have concentrated on discriminating among the earth surface materials such as vegetation, Land Use/Land Cover (LUC), bare surface and erosion mapping; in very few of them has remote sensing been used for soil property mapping. For example, Eniolorunda et al. (2015) identified colluvial sand in the Rima river floodplain based on LUC mapping, while Aizebeokhai et al. (2018) performed soil characterization in some parts of the southwestern Nigeria using remote sensing technique. Fasina et al. (2015), in their study, combined the conventional and remote sensing methods for soil characterization and classification in Ijebu East of southwestern Nigeria. The above studies used proximate methods to delineate soil boundaries, which are also computationally rigorous and time consuming. In this study, a direct and cheaper method is proposed where the brightness image of Kauth-Thomas Tasseled Cap Transformation (TCT) is used to present soil textural information. Features derived from TCT can be directly associated with important physical parameters of the land surface that are more easily understood (Liu et al., 2015). The aim of this study is to test the applicability of Kauth-Thomas TCT to soil textural mapping on the main campus of Usmanu Danfodiyo University, Sokoto. The objectives include derivation of the KauthThomas TCT image, determination of soil particle size and Land use/ Land Cover mapping. We hypothesized that the brightness image of the study area has no correlation with soil particle size on the one hand and that soil texture has no relationship with LUC on the other hand.

\subsection{Methodology}

\subsection{Study area}

The study was conducted on the main campus of Usmanu Danfodiyo University, Sokoto. It is located within latitude $13^{\circ} 6^{\prime} 30^{\prime \prime}-13^{\circ} 08^{\prime} 30^{\prime \prime}$ North and longitudes $5^{\circ} 11^{\prime} 30^{\prime \prime}-5^{\circ} 14^{\prime} 30^{\prime \prime}$ East (Figure 1). It lies in the north of Sokoto-Rima river floodplain with land area of $697 \mathrm{~km}^{2}$. The area lies within the Iullemeden basin which is underlain by Precambrian basement complex. It is covered by a series of sedimentary rocks which have been deposited over time. These sediments were laid down under varied environmental situations ranging from continental to marine events. The study area is located within the Kalambaina formation which is aquieferous. It has an altitude of $312 \mathrm{~m}$ above sea level. The soil type found at the site is regosol. This type of soil is weakly developed due to slow soil formation process as water cannot easily drain through the profile. The top soil is generally sandy, resulting from sand dune deposition from the far away Sahara desert, while the subsoil is clayed due to illuviation of clay materials from the topsoil. In some places, soil profile is characterized by absence of $A$ horizon due to removal by human activities and erosion. What appears as the topsoil is the $B$ horizon which is in two layers: $B_{1}$ and $B_{2}$. The former is found within $0-35 \mathrm{~cm}$; it is sandy clay with blocky structure, bulk density of $1.43 \mathrm{~g} / \mathrm{cm}^{3}$ and soil moisture content of $1.3 \%$. The latter is found within $35-150 \mathrm{~cm}$; it is clay with platy structure, bulk density of $1.47 \mathrm{~g} / \mathrm{cm} 3$ and $11.61 \%$ soil moisture content. 


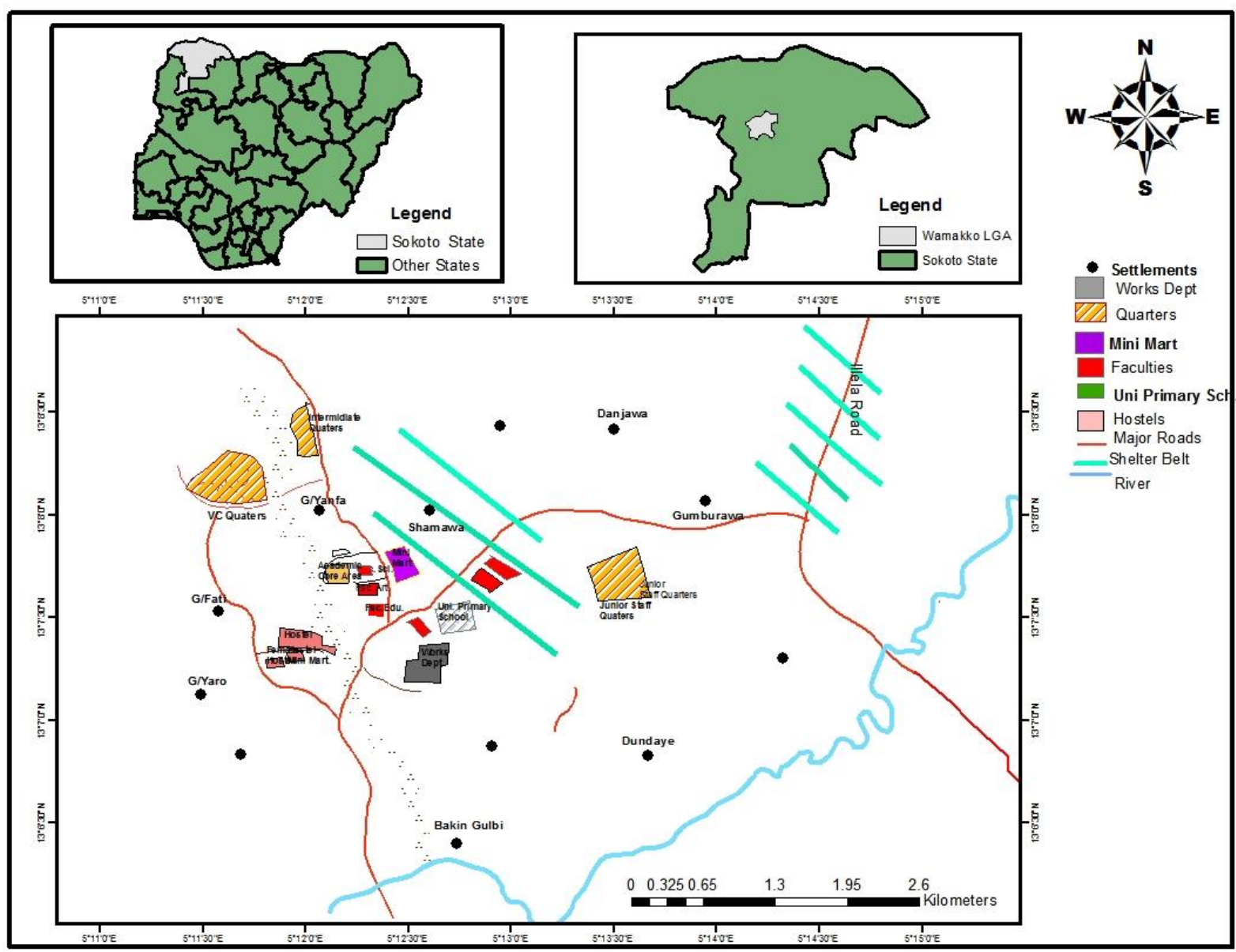

Figure 1: Map of the study area

The area is located in the semi-arid region of Nigeria. With an annual average temperature of $28.3{ }^{\circ} \mathrm{C}$ $\left(82.9^{\circ} \mathrm{F}\right)$, Sokoto is one of the hottest states in Nigeria, however the maximum daytime temperatures are generally under $40^{\circ} \mathrm{C}\left(104.0^{\circ} \mathrm{F}\right)$ most of the year, and the dryness makes the heat unbearable. The warmest months are February to April, where daytime temperatures can exceed $45^{\circ} \mathrm{C}\left(113.0^{\circ} \mathrm{F}\right)$. The highest recorded temperature is $47.2^{\circ} \mathrm{C}\left(117.0^{\circ} \mathrm{F}\right)$. The rainy season ranges between June and October.

The area has population of 176,619 at the 2006 census and mainly populated by rural dwellers most of whom are farmers and herders

\subsection{Methods}

\subsubsection{Image processing}

Landsat 8 OLI-TIRs of 22-03-2019 (path/row 191/051) was downloaded from the United States Geological Survey Department (USUGS) Earth Explorer site: earthexplorer.usgs.gov. Using the attendant metadata, Bands 2 to 7 were converted into top-of-atmosphere (TOA) reflectance images for atmospheric correction (Liu et al., 2015; Yarbrough et al., 2014), carried out within the QGIS software. Reflectance rescaling coefficients found in the metadata MTL text file were applied. This saw the conversion of the 12-bit OLI bands into 8-bit. The size of the study area was subsequently sub-mapped from all the six bands (bands 2-7), after which they were geometrically corrected at Root Mean Square (RMS) error of 0.03 using the method described by Eniolorunda et al. (2017). KauthThomas Tasseled Cap Transformation was performed on the six bands to extract three index bands of the OLI. The Brightness image refers to soil brightness, while the Greenness band, sometimes referred to as Green Vegetation Index or GVI, which highlights green vegetation cover or biomass above ground (Eastman, 2017). The Wetness image represents soil moisture. The formulas are as written in Equations 1 to 3 as proposed by Baig et al. (2014) written as:

$$
\begin{aligned}
& \text { OLI Bright }=(\text { Band } 2 * 0.3029)+(\text { Band } 3 * 0.2786)+(\text { Band } 4 * 0.4733)+(\text { Band } 5 * \\
& 0.5599)+(\text { Band } 6 * 0.5080)+(\text { Band } 7 * 0.1872)
\end{aligned}
$$




$$
\begin{aligned}
& \text { OLI Green }=(\text { Band } 2 *(-0.2941))+(\text { Band } 3 *(-0.2430))+(\text { Band } 4 *(-0.5424))+ \\
& (\text { Band } 5 * 0.7276)+(\text { Band } 6 * 0.0713)+(\text { Band } 7 *(-0.1608)) \\
& \text { OLI Wet }=(\text { OLI } 2 * 0.1511)+(\text { OLI } 3 * 0.1973)+(\text { OLI } 4 * 0.3283)+(\text { OLI } 5 * 0.3407)+ \\
& (\text { OLI6 } *(-0.7117))+(\text { OLI7 } *(-0.4559))
\end{aligned}
$$

where:

OLI Bright, OLI Green and OLI Wet are the Brightness, Greenness and Wetness images respectively.

In this study, the brightness image was used for soil texture mapping.

\subsubsection{Unsupervised classification}

The brightness image, hereafter referred to as TCT-Brightness image, was subjected to unsupervised classification using cluster algorithm within the Idrisi Terrset environment. The resultant map was used as the template for identifying the locations for soil sampling based on stratified random sampling method.

\subsubsection{Soil sampling and laboratory treatment}

Locations of sites for soil sampling were identified on the map produced by unsupervised classification. Soil samples were collected using stratified random sampling at 91 points, excluding the built-up areas. For each location which is a $30 \mathrm{~m} * 30 \mathrm{~m}$ quadrat, four subsamples were collected randomly, bulked and homogenized (Pennock et al., 2006). Soil particle size was determined using Bouyoucos Hydrometer method as described by Kroetsch and Wang (2006).

\subsubsection{Soil particle size modelling}

A model was developed for each of the particle sizes using simple linear regression equation:

$$
\begin{array}{ll}
Y=a+b X \\
\text { where: } & \\
Y & \text { particle size (dependent variable), } \\
X & \text { TCT image (independent variable), } \\
a & \text { value of } Y \text { when } X \text { is zero, } \\
b & \text { coefficient of } X
\end{array}
$$

The particle sizes of the sampled points and their corresponding pixel values form the inputs to the model. The regression analysis was differently performed for sand, silt and clay to obtain three different models.

\subsubsection{Soil textural mapping}

In mapping the soil texture, the above model was applied to develop particle size map for each of the soil separates. These were then combined within the SAGA environment to produce the textural map.

\subsubsection{Land Use/ Land Cover (LUC) classification}

Land Use/Land Cover (LUC) for the year 2019 was used in this study for comparison with soil textural map. The LUC mapping of the study area was performed using the Classification and Regression Tree Machine Learning within the Google Earth Engine (GEE) as described by Farda (2017), Kumar and Mutanga (2017). Landsat 8 Collection 1 Tier 32-Day TOA Reflectance Composite covering between 06/03/2019 and 07/04/2019 was accessed via GEE for the mapping at Level II of Anderson et al. (1976) scheme.

\subsubsection{Relationship between soil texture and LUC}

Cross-Map Tabulation (CMT) was carried out between the LUC and soil texture maps. Cramer's V and Kappa index of agreement were used to either accept or reject the null hypothesis that LUC does not affect soil texture 


\subsection{Results and Discussion}

\subsection{Kauth-Thomas Tasseled Cap Transformation (TCT) brightness image}

The TCT-Brightness image was derived by combining the six bands of the Landsat 8 image. Figure 2 shows a 12 to 8-bit calibration based on TOA conversion. Thus, the brightness image pixel values range between 109.14 and 197.74, while most of the values hover around 151.31 (Figure 3). A standard deviation of 11.81 suggests high spatial variability in soil texture of the area. This reasonably hints of the heterogeneity of Land Use/Land Cover (LUC) types in the area as opposed to homogeneity that generally characterizes such a semi-arid environment particularly when vegetation is not in the high biomass period (Liu et al., 2015). Liu et al. (2015) further argued that the outcome of TCT can be influenced by season. Although TCT output may vary temporally, the dry season textural information derived from the brightness image of the study area can be valid as soil textural changes require long periods of time with the active function of other factors of soil formation. This is in conformity with the submission of Abdulrashid and Yaro (2014) and Abdulrashid and Mashi (2014) on soil textural change in the semi-arid environments.

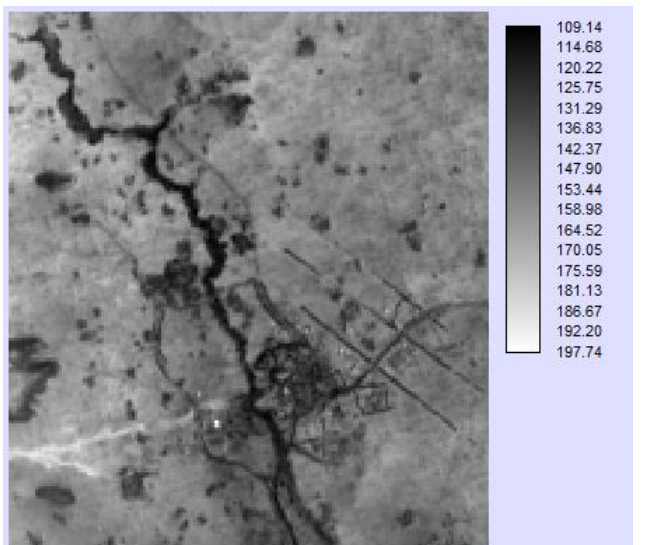

Figure 2: TCT-Brightness image

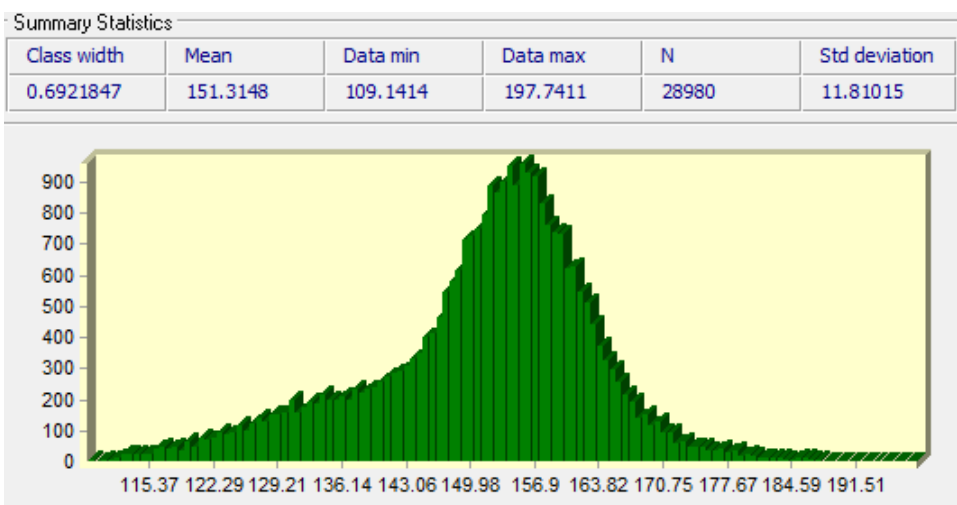

Figure 3: Histogram of TCT-Brightness image

\subsection{Soil particle size determination and modelling}

\subsubsection{Soil particle size determination}

The unsupervised classification carried out on the TCT-Brightness image is presented in Figure 4. The map which has 5 clusters was used to guide in the selection of soil samples which were collected based on stratified random sampling. The descriptive statistics of the textural classes derived from the samples and their corresponding pixel values are presented in Table 1. Four soil textural classes are observed in the area: loamy sand, sand, sandy-clay-loam and sandy loam. Sand particles have the highest mean pixel value of 170.22 , followed by loamy sand with 149.26 . Sandy loam particles have a mean value of 135.39 , while sandy clay loam particles have the least mean value of 111.10 . Spectral reflectance patterns of soil separates indicate that sand is the most reflective, followed by silt; clay has the least reflectance across wavelengths (Thomasson et al., 2013). It is plausible to opine in this study that the less the sand particles the less the spectral value in the TCT-Brightness image. In other words, the more the clay content available in the soil the less the reflectance. 


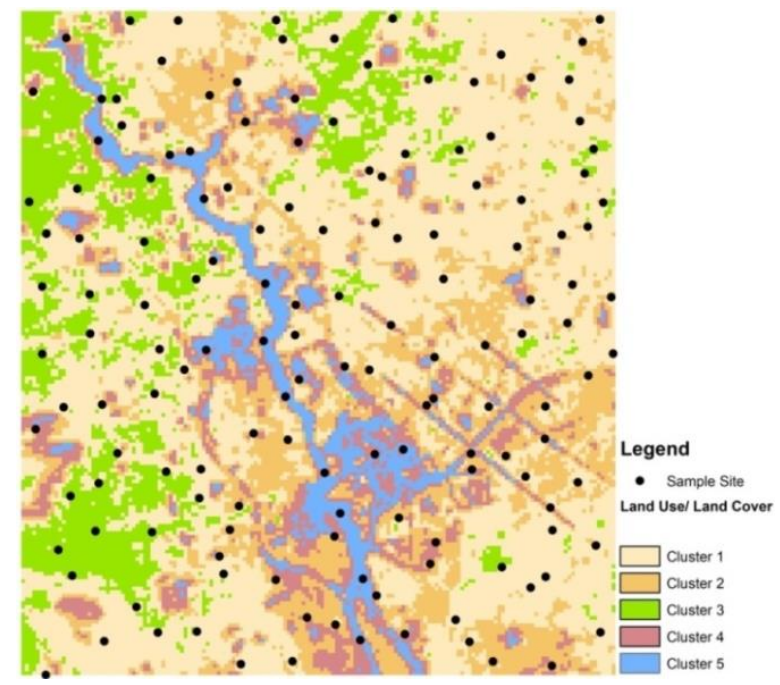

Figure 4: Sample locations on unsupervised classification map

Table 1: Soil textural classes and descriptive charateristics of corresponding brightness pixel values

\begin{tabular}{|l|c|c|c|}
\hline Texture & Sample Size & Brightness Image Mean Pixel Value & Standard Deviation of Pixel Values \\
\hline Sandy Clay Loam & 22 & 111.10 & 4.15 \\
\hline Loamy Sand & 17 & 149.26 & 1.63 \\
\hline Sand & 34 & 170.22 & 6.80 \\
\hline Sandy Loam & 18 & 135.39 & 4.85 \\
\hline
\end{tabular}

\subsubsection{Soil particle size modelling}

The TCT-Brightness image was used to model particle size in this study. Thus, particle sizes were differently regressed on brightness pixel values. The regression outputs for sand are contained in Table 2. It can be seen that $\mathrm{R}$ which represents the correlation coefficient between the independent variable (TCT-Brightness image values) and the dependent variable (\%Sand) is positive and high (0.904). The R squared shows that about $82 \%$ of the variance in the \%Sand is explained by the TCTBrightness image values. That $\mathrm{P}<0.01$ for $\mathrm{F}$ value indicates the regression is significant and TCTBrightness image values can be used to predict \%Sand in the study area. The model is therefore shown in Equation 5 as:

$$
\% \text { Sand }=0.547 *(\text { brightness image })-10.195
$$

The model for silt can also be extracted from the regression outputs in Table 3. Although $R=0.82$, the Standardized Coefficients (Table 3) indicates that the correlation between the TCT-Brightness image values and \%Silt is negative, while the $\mathrm{R}$ squared indicates that $67.2 \%$ of the variance in the $\%$ Silt is explained by the brightness image values. The regression is significant where $\mathrm{P}<0.01$ for $\mathrm{F}$ value, indicating that brightness image can be used to predict the \%Silt composition. Thus, the regression equation is shown in Equation 6 as:

$$
\% \text { Silt }=47.985-0.225 *(\text { brightness image })
$$

The \%Clay was also regressed on TCT-Brightness pixel values, and the outputs are presented in Table. Similarly, the brightness image negatively correlates with \% Clay, as the Standardized Coefficients value is -0.898 (Table 4), explaining about $81 \%$ of the variation in \%Clay. The overall regression is significant $(\mathrm{P}<0.01)$, and the model can be written thus:

$$
\% \text { Clay }=62.21-0.323 *(\text { brightness image })
$$


Table 2: Regression output for sand

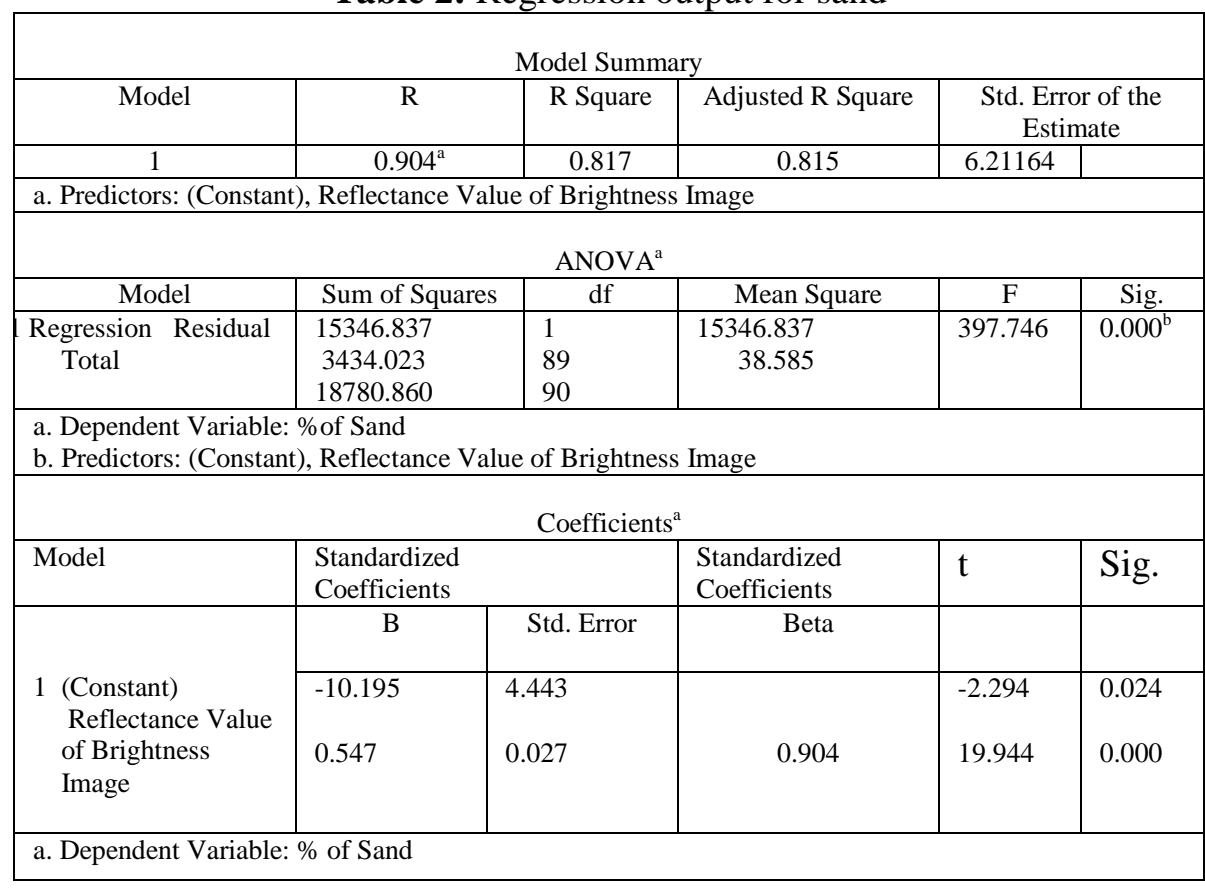

Table 3: Regression output for silt

\begin{tabular}{|c|c|c|c|c|c|}
\hline \multicolumn{6}{|c|}{ Model Summary } \\
\hline Model & $\mathrm{R}$ & R Square & Adjusted R Square & \multicolumn{2}{|c|}{$\begin{array}{l}\text { Std. Error of the } \\
\text { Estimate }\end{array}$} \\
\hline 1 & $0.820^{\mathrm{a}}$ & 0.672 & 0.668 & 3.77195 & \\
\hline \multicolumn{6}{|c|}{ a. Predictors: (Constant), Reflectance Value of Brightness Image } \\
\hline \multicolumn{6}{|c|}{ ANOVA $^{\mathrm{a}}$} \\
\hline Model & Sum of Squares & $\mathrm{df}$ & Mean Square & $\mathrm{F}$ & Sig. \\
\hline $\begin{array}{ll}1 & \text { Regression } \\
& \text { Residual } \\
\text { Total }\end{array}$ & $\begin{array}{c}2590.779 \\
1266.257 \\
3857.037\end{array}$ & $\begin{array}{l}1 \\
89 \\
90\end{array}$ & $\begin{array}{c}2590.779 \\
14.228\end{array}$ & 182.095 & $0.000^{b}$ \\
\hline \multicolumn{6}{|c|}{$\begin{array}{l}\text { a. Dependent Variable: } \% \text { of Silt } \\
\text { b. Predictors: (Constant), Reflectance Value of Brightness Image }\end{array}$} \\
\hline \multicolumn{6}{|c|}{ Coefficients $^{\mathrm{a}}$} \\
\hline Model & \multirow{2}{*}{\multicolumn{2}{|c|}{$\begin{array}{c}\begin{array}{l}\text { Standardized } \\
\text { Coefficients }\end{array} \\
\end{array}$}} & $\begin{array}{l}\text { Standardized } \\
\text { Coefficients }\end{array}$ & $\mathrm{t}$ & Sig. \\
\hline \multirow[b]{2}{*}{$\begin{array}{l}1 \text { (Constant) } \\
\text { Reflectance Value } \\
\text { of Brightness } \\
\text { Image }\end{array}$} & & & Beta & & \\
\hline & $\begin{array}{l}47.985 \\
-0.225\end{array}$ & $\begin{array}{l}2.698 \\
0.017\end{array}$ & -0.820 & $\begin{array}{l}17.784 \\
-13.494\end{array}$ & $\begin{array}{l}0.000 \\
0.000\end{array}$ \\
\hline & Silt & & & & \\
\hline
\end{tabular}


Table 4: Regression output for clay

\begin{tabular}{|c|c|c|c|c|c|}
\hline \multicolumn{6}{|c|}{ Model Summary } \\
\hline Model & $\mathrm{R}$ & R Square & Adjusted R Square & \multicolumn{2}{|c|}{$\begin{array}{l}\text { Std. Error of the } \\
\text { Estimate }\end{array}$} \\
\hline 1 & $0.898^{\mathrm{a}}$ & 0.806 & 0.804 & 3.79450 & \\
\hline \multicolumn{6}{|c|}{ a. Predictors: (Constant), Reflectance Value of Brightness Image } \\
\hline \multicolumn{6}{|c|}{ ANOVA $^{\mathrm{a}}$} \\
\hline Model & Sum of Squares & df & Mean Square & $\mathrm{F}$ & Sig. \\
\hline $\begin{array}{ll}1 & \text { Regression } \\
& \text { Residual } \\
& \text { Total } \\
\end{array}$ & $\begin{array}{c}5326.468 \\
1281.445 \\
6607.913 \\
\end{array}$ & $\begin{array}{l}1 \\
89 \\
90\end{array}$ & $\begin{array}{c}5326.468 \\
14.398\end{array}$ & 369.938 & $0.000^{\mathrm{b}}$ \\
\hline \multicolumn{6}{|c|}{$\begin{array}{l}\text { a. Dependent Variable: \% of Silt } \\
\text { b. Predictors: (Constant), Reflectance Value of Brightness Image }\end{array}$} \\
\hline \multicolumn{6}{|c|}{ Coefficients ${ }^{\mathrm{a}}$} \\
\hline Model & \multicolumn{2}{|c|}{$\begin{array}{l}\text { Standardized } \\
\text { Coefficients }\end{array}$} & $\begin{array}{l}\text { Standardized } \\
\text { Coefficients }\end{array}$ & $\mathrm{t}$ & Sig. \\
\hline \multirow[b]{2}{*}{$\begin{array}{l}1 \text { (Constant) } \\
\text { Reflectance Value } \\
\text { of Brightness } \\
\text { Image }\end{array}$} & B & Std. Error & Beta & & \\
\hline & $\begin{array}{l}62.210 \\
-0.323\end{array}$ & $\begin{array}{l}2.714 \\
0.017\end{array}$ & -0.898 & $\begin{array}{l}22.919 \\
-19.234\end{array}$ & $\begin{array}{l}0.000 \\
0.000\end{array}$ \\
\hline$n+\mathrm{Va}$ & f Clay & & & & \\
\hline
\end{tabular}

\subsubsection{Model test}

For assurances that the TCT-Brightness image can be used to predict soil texture for the study area, the predictive models for the particle sizes in Equations 5, 6 and 7 were put to test using arbitrarily selected values from the TCT-Brightness image one after the other. Table 5 describes the outcomes. Since the particle sizes must add up to $100 \%$, the total in Table 5 can be taken for the accuracy of the models. An error range of between 0.1 and 0.2 is unaccounted for. Thus, it is plausible to rewrite the equations as:

$$
\begin{aligned}
& \% \text { of Sand }=0.547 *(\text { brightness image })-10.195+E \\
& \% \text { of Silt }=47.985-0.225 *(\text { brightness image })+E \\
& \% \text { of Clay }=62.21-0.323 *(\text { brightness image })+E
\end{aligned}
$$

where $E$ is the inherent error.

In this study, $E$ is calculated as an average of the above stated errors which is 0.15 . This value is added in the computation of each soil separate map. Figures 5, 6 and 7 are the maps of soil separate for the study area. In each of the images, areas of dark tones are of low values for that particular variable. When combined, the pixels in the three images will complementarily add up to $100 \%$ to produce the soil textural map for the area.

Table 5: Outputs of model test

\begin{tabular}{|c|c|c|c|c|c|c|}
\hline Number & Brightness Value & \% Sand & \% Silt & \% Clay & Total & Textural Class \\
\hline 1 & 120 & 55.445 & 20.985 & 23.45 & 99.9 & Sandy Clay Loam \\
\hline 2 & 130 & 60.915 & 18.735 & 20.22 & 99.9 & Sandy Clay Loam \\
\hline 3 & 140 & 66.385 & 16.485 & 16.99 & 99.9 & Sandy Loam \\
\hline 4 & 150 & 71.855 & 14.235 & 13.76 & 99.9 & Sandy Loam \\
\hline 5 & 160 & 77.325 & 11.985 & 10.53 & 99.8 & Sandy Loam \\
\hline 6 & 170 & 82.795 & 9.735 & 7.3 & 99.8 & Loamy Sand \\
\hline 7 & 180 & 88.265 & 7.485 & 4.07 & 99.8 & Sand \\
\hline 8 & 190 & 93.735 & 5.235 & 0.84 & 99.8 & Sand \\
\hline
\end{tabular}




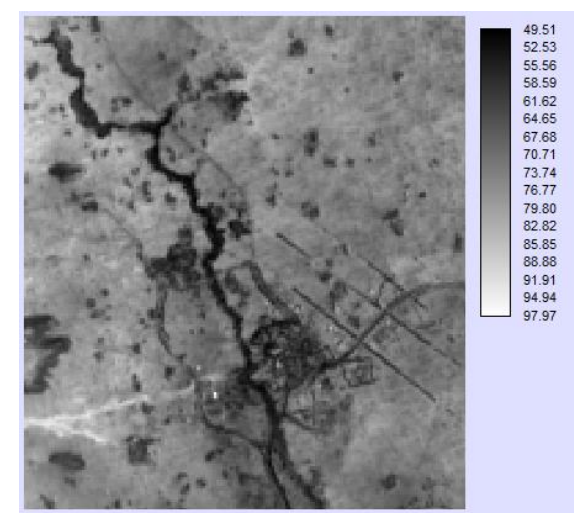

Figure 5: \%Sand

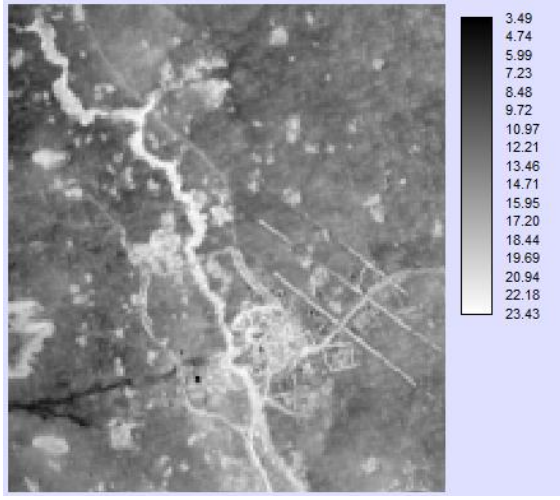

Figure 6: \%Silt

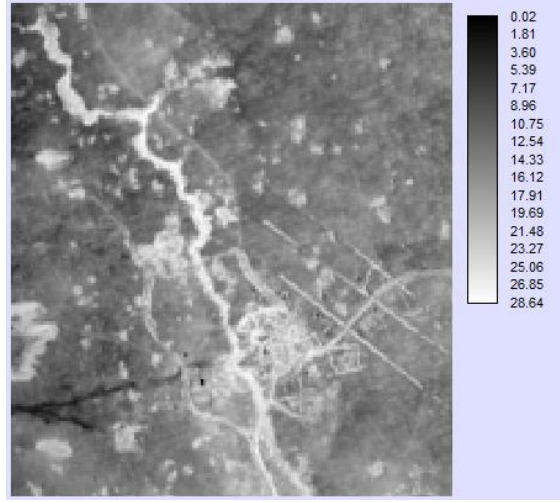

Figure 7: \%Clay

\subsubsection{Soil textural mapping}

The maps of soil separates (Figures 5, 6 and 7) were combined within the SAGA environment to produce the textural map (Figure 8). The accuracy test of the textural map was performed by purposively sampling five points from each of the textural classes for ground verification. Table 6 presents the error matrix. The overall accuracy which is the proportion of the selected samples correctly mapped is given as:

$\mathrm{OA}=$ number of correctly classified pixels*100/sample size

where OA is the Overall Accuracy.

Table 6: Error Matrix: Ground Truth 2019 (Columns) against Textural Classes 2019 (rows)

\begin{tabular}{|l|r|r|r|r|r|}
\hline & SCL & LS & S & SL & Total \\
\hline SCL & $\mathbf{0 5}$ & 00 & 00 & 00 & 05 \\
\hline LS & 00 & $\mathbf{0 4}$ & 00 & 00 & 04 \\
\hline S & 00 & 00 & $\mathbf{0 5}$ & 00 & 05 \\
\hline SL & 00 & 01 & 00 & $\mathbf{0 5}$ & 06 \\
\hline Total & 05 & 05 & 05 & 05 & $\mathbf{2 0}$ \\
\hline
\end{tabular}

In this case, the OA is $95 \%$, and this implies that the soil texture of the area is accurately mapped. Although there is no universal benchmark for accuracy assessment in image classification (Eniolorunda et al., 2017), the value obtained in this study is above the usually referenced $85 \%$ in the literature.

Figure 8 and Table 7 show that sandy soil is dominant in the study area. Studies have indicated that the top soil in most parts of Sokoto State is generally sandy, resulting from sand dune deposition from the far away Sahara desert. The sandy nature of the area can also be attributed to the low rate of soil formation in the environment due to low annual rainfall amount and temporal spread. Soil texture is an important physical characteristic of soil which has great significance in land use management (Mohamed and Abdo, 2011). Soils dominated by sand particles drain water very quickly but have lower fertility. 


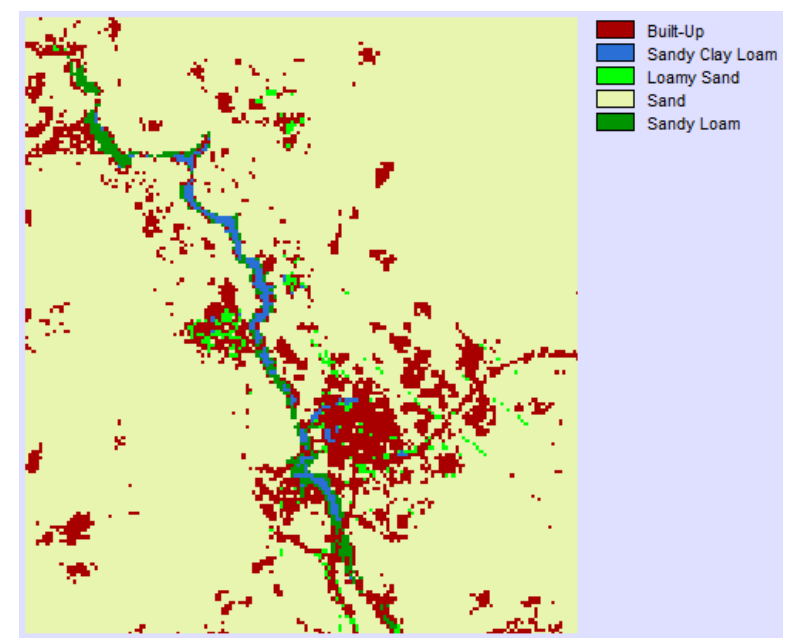

Figure 8: Soil textural map of the study area

Table 7: Area coverage of Soil Texural Classes

\begin{tabular}{|l|c|c|}
\hline Texture & Area Coverage (Ha) & Percent \\
\hline Built-up Area & 272.97 & 10.47 \\
\hline Sandy Clay Loam & 23.76 & 0.91 \\
\hline Loamy Sand & 23.22 & 0.89 \\
\hline Sand & $2,255.31$ & 86.47 \\
\hline Sandy Loam & 32.94 & 1.26 \\
\hline Total & $\mathbf{2 6 0 8 . 2 0}$ & $\mathbf{1 0 0}$ \\
\hline
\end{tabular}

\subsection{Land Use/ Land Cover Mapping}

The Land Use/Land Cover (LUC) mapping was carried out at level III of Anderson et al. (1976) Classification scheme with the Landsat 8 of 2019 using the Classification and Regression Tree Machine Learning within the Google Earth Engine (GEE) as described by Farda (2017) and Kumar and Mutanga (2017). Five classes were derived namely: Built-up area, Wetland, Upland Forest, Bare Surface and Riparian Forest (Figure 9 and Table 8). A classification accuracy of $98.3 \%$ was automatically reported.

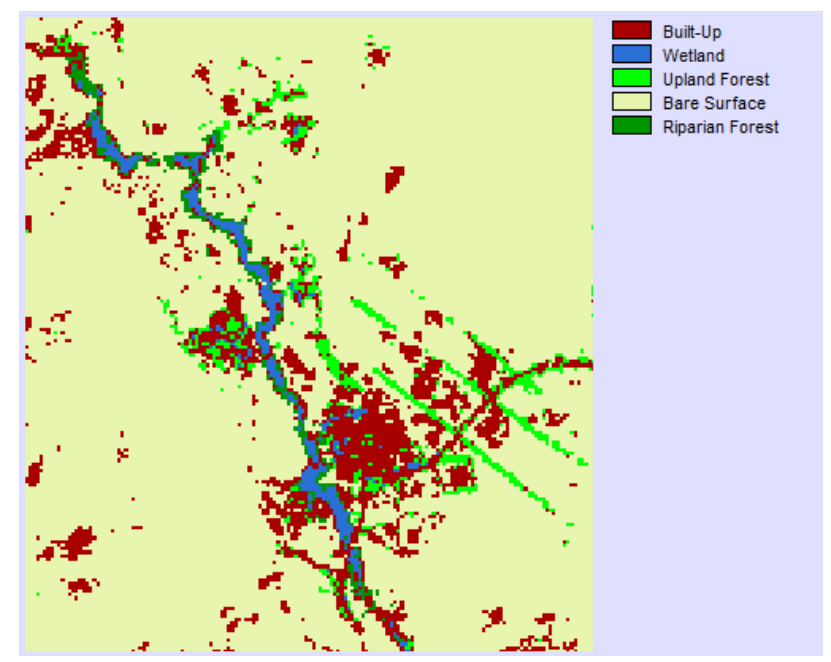

Figure 9: LUC of the study area 
Table 8: Description of LUC

\begin{tabular}{|l|r|r|}
\hline \multicolumn{1}{|c|}{ LUC } & Hectares & Percentage Coverage \\
\hline Built-Up & 273.69 & 10.49 \\
\hline Wetland & 44.01 & 1.69 \\
\hline Upland Forest & 78.75 & 3.02 \\
\hline Bare Surface & 2177.37 & 83.48 \\
\hline Riparian Forest & 34.38 & 1.32 \\
\hline Total & 2608.20 & 100 \\
\hline
\end{tabular}

The built-up area covers about $10.5 \%$ of the area; it is made up of the university structures and the surrounding settlements which are largely agrarian. The university serves as a spring board for the growth and expansion of old surrounding settlements as well as an impetus for emergence of new ones. Thus, rate of LUC change is expectedly high, thereby impacting on the soil surficial texture and structure. The wetland traverses diagonally through the area with northwest-southeast orientation, accounting for $1.69 \%$ of the area. It is cultivated with food crops all the year round. The upland forests are greenbelts that are essentially composed of Azadirachta indica (neem) (Dóógón yááròò). Because they grow upland, rate of addition and decay of organic matter is slow; thus, soil texture expectedly improves slowly. However, the forests protect the soil against wind and water erosion. The bare surface has the largest coverage of about 2, 177ha (83.5\%). It is largely farmland which during the rainy season is either grassy or grown with grains but left bare in the dry season after harvest. The top soil undergoes mixing through the process of cultivation and herding. Because the surface is bare, it is unprotected from erosion and deposition. The riparian forests are associated with the wetland in the study area, occupying 34.4ha (1.32\%). They are essentially composed of Mangifera indica (mango) (Màngwàrò). The input of organic matter from this species is higher than that of Azadirachta indica. The coupling of high organic matter input and wetness of soil will affect soil texture (Stanchi et al., 2015; van-Hall et al., 2017).

\subsection{Relationship between Soil Texture and Land Use Land Cover}

A visual comparison shows that Figures 8 and 9 are similar. The Built-Up class was masked from both maps as it was not sampled. Cartographic overlay shows that sandy-clay-loam is associated with wetland, while loamy sand is related to upland forest; sand is largely associated with bare surface, while sandy loam is related to riparian forest. To statistically establish these relationships, cross maptabulation of the soil texture map (Figure 8) and LUC map (Figure 9) was carried out. Figure 10 and Table 9 present the results.

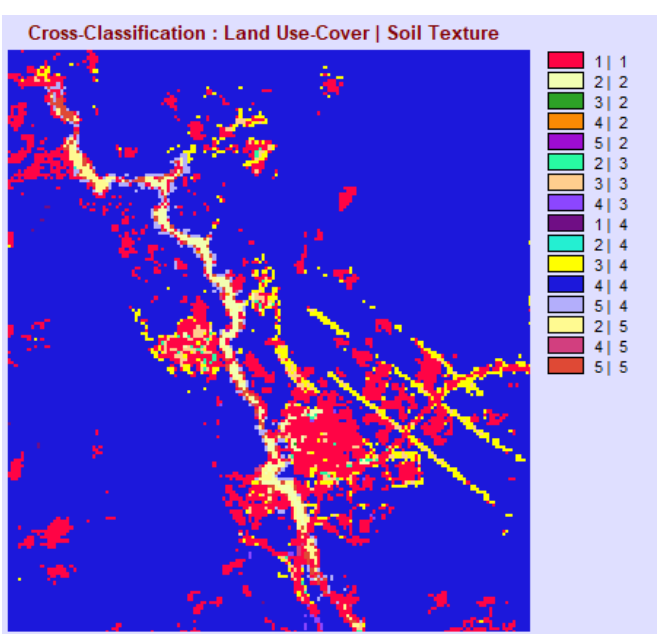

Figure 10: Cross-Tabulation Map 
Table 9: Pixel Cross-tabulation Using Land Use-Cover (columns) vs. Soil Texture (rows)

\begin{tabular}{|c|c|c|c|c|c|c|}
\hline Category & 1 & 2 & 3 & 4 & 5 & Total \\
\hline 1 & 3033 & 0 & 0 & 0 & 0 & 3033 \\
\hline 2 & 0 & 257 & 1 & 4 & 2 & 264 \\
\hline 3 & 0 & 45 & 192 & 21 & 0 & 258 \\
\hline 4 & 8 & 1 & 682 & 24150 & 218 & 25059 \\
\hline 5 & 0 & 186 & 0 & 18 & 162 & 366 \\
\hline Total & 3041 & 489 & 875 & 24193 & 382 & 28980 \\
\hline
\end{tabular}

Chi-square $=59632.1055, \mathrm{df}=16$, P-Level $=0.0000$, Cramer's V $=0.7172$, Overall Kappa: 0.8465

The diagonal values in Table 9 are the number of pixels in agreement in both maps, while offdiagonals are outlying pixels. An overall Kappa Index of Agreement (KIA) of 0.85 confirms a significantly $(\mathrm{p}<0.01)$ high relationship between texture and LUC, as Viera and Garrett $(2005)$ submitted that a KIA above 0.8 is almost a perfect agreement. In a previous study of land use land cover change effect on soil characteristics around the study area, Eniolorunda (2016) observed different soil textural classes across the LUC classes. Relatedly, Biro et al. (2011) observed changes in soil texture due to land use land cover change (LUCC) in an agricultural area in the dry land of Sudan, while Majaliwa et al. (2011) also observed variation in clay fraction in different LUCs in Uganda. In a study conducted on the effects of land-use changes on soil properties in a Humid Northern Blacksea Region, Yuksek et al.(2009) established a relationship between land use change and soil texture change. Land use and land use change has an adverse effect on soil characteristics such as permeability, soil texture and aggregate stability (Jeloudar et al., 2018). Soil texture is an important physical characteristic of soil which has great significance in land use management (Mohamed and Abdo, 2011).

\subsection{Conclusions}

The study tested the applicability of Kauth-Thomas TCT for soil textural mapping in the study area. TCT-Brightness image was derived from the original bands of the OLI image. Soil particle sizes were determined by soil sampling which yielded sandy-clay-loam, loamy sand, sand and sandy loam. Simple linear regression analysis was used to model soil particle sizes from the TCT-Brightness image with an average accuracy of $99.85 \%$. Soil textural map was produced by combining maps of soil separates at 95\% accuracy. Land use/ Land Cover (LUC) of the area was mapped at $98.3 \%$ of accuracy within the GEE environment to produce 5 classes namely built-up area, wetland, upland forest, bare surface and riparian forest. Cross map-tabulation was carried out to test for the extent of relationship between LUC and soil texture with an overall Kappa Index of Agreement of 0.85, attesting to an almost perfect relationship. This study concludes that the Kauth-Thomas Tasseled-Cap Transformation (TCT) can be used for rapid soil textural assessment in the study area especially in the dry season. We recommend a repeat of this study for the wet season.

\section{References}

Abdulrashid, L. and Mashi, S.A. (2014) Soil Degradation in Marginal Areas: Perspectives of Farming Communities of Semi-Arid Areas of Katsina State, Northern Nigeria. International Journal of Innovative Research and Development, 3, pp. 449-460.

Abdulrashid, L. and Yaro, A. (2014) Local Theories on Soil Formation and Classifications by Farming Communities of Semi-Arid Areas of Katsina State, Nigeria. Journal of Environment and Earth Science, 4, pp. 65-67.

Aizebeokhai, A. P., Okenwa, U. N., Oyeyemi, K. D., Kayode, O. T., and Adeyemi, G. A. (2018). Soil characterization using satellite remote sensing in southwestern Nigeria: Implications for precision agriculture. IOP Conference Series: Earth and Environmental Science, 173(1).

Anderson J. R., Hardy E.E., Roach J. T. and Witmer R.E. (1976). A land use and land cover classification system for use with remote sensor data. Geological Survey Professional paper 964. A revision of the land use classification system as presented in U.S. Geological Survey Circular 671.

Baig, M. H. A., Zhang, L., Shuai, T. and Tong, Q. (2014). Derivation of a tasseled cap transformation based on Landsat 8 at satellite reflectance. Remote Sensing Letters, 5(5), pp. 423-431. 
Biro K., Pradhan B., Buchroithner M. and Makeschin F. (2011). Land use/Land cover change analysis and its impact on soil properties in the Northern part of Gadarif Region, Sudan. Land degradation and Development, 2011.

Casa, R., Castaldi, F., Pascucci, S., Palombo, A., and Pignatti, S. (2013). Geoderma A comparison of sensor resolution and calibration strategies for soil texture estimation from hyperspectral remote sensing. Geoderma, 197-198, pp. 17-26.

Dewitte, O., Jones, A., Elbelrhiti, H., Horion, S., and Montanarella, L. (2012). Satellite remote sensing for soil mapping in Africa: An overview. Progress in Physical Geography, 36(4), pp. 514538.

Eastman J. R. (2017). Idrisi Terrset Tutorial, Clark Lab, Clark University.

Eniolorunda N. B. (2016). Land Use/Land Cover Change and Soil Quality in the Rima River Floodplain, Sokoto, Nigeria. An unpublished PhD Thesis, Umaru Musa Yar'Adua University, Katsina, Katsina State, Nigeria.

Eniolorunda N. B., Mashi S. A. and Nsofor G. N., Abubakar S. D. and Yaro A. (2015). Land Use/Land Cover change-induced sand delivery into the Floodplain of Rima River around Wamakko area of Sokoto State, Nigeria. Journal of Geographic Thought and Environmental Studies, 13(3), pp. $162-179$.

Eniolorunda, N. B., Mashi, S. A., and Nsofor, G. N. (2017). Toward achieving a sustainable management: characterization of land use/land cover in Sokoto Rima floodplain, Nigeria. Environment, Development and Sustainability, 19(5), pp. 1855-1878.

Farda N. M. (2017) Multi-temporal Land Use Mapping of Coastal Wetlands Area using Machine Learning in Google Earth Engine Multi-temporal Land Use Mapping of Coastal Wetlands Area using Machine Learning in Google Earth Engine. IOP Conference Series: Earth and Environmental Science 98012042.

Fasina, A. S., Raji, A., Oluwatosin, G. A., Omoju, O. J., and Oluwadare, D. A. (2015). Properties , Genesis , Classification, Capability and Sustainable Management of Soils from South-Western Nigeria. International Journal of Soil Science, 10(3), pp. 142-152.

Hartemink, A. E., and Minasny, B. (2014). Towards digital soil morphometrics. Geoderma, 230-231, pp. 305-317.

Jeloudar, F. T., Sepanlou, M. G., and Emadi, S. M. (2018). Impact of land use change on soil erodibility. Global Journal of Environmental Science and Management, 4(1), pp. 59-70.

Kroetsch D. and Wang C. (2006). Particle Size Distribution. In Cater M. R. and Gregorich E. G., Soil Sampling and Methods of Analysis, $2^{\text {nd }}$ Edition, Taylor and Francis Group, LLC.

Kumar, L., and Mutanga, O. (2019). Google Earth Engine Applications. Remote Sensing, 2019, 11, 591.

Liu, Q., Liu, G., Huang, C., and Xie, C. (2015). Comparison of tasseled cap transformations based on the selective bands of Landsat 8 OLI TOA reflectance images. International Journal of Remote Sensing, 36(2), pp. 417-441.

Majaliwa J. G. M., Twongyirwe R., Nyenje R., Olukan M., Ongom B., et al. (2011): The effect of land cover change on soil properties around Kibale National Park in South Western Uganda. Applied and Environmental Soil Science, 2010. 
Menezes, M.D.d., Silva, S.H.G., Mello, C.R.d., Owens, P.R., Curi, N., (2014). Solum depth spatial prediction comparing conventional with knowledge-based digital soil mapping approaches. Scientia Agricola 71(4), pp. 316-323.

Mohamed M. Y. and Abdo B. M. (2011): Spatial variability of some soil properties in El-Multagha agricultural project (Sudan) using Geographic Information systems (GIS) techniques. Journal of Soil Science and Environmental Management, 2(2), pp. 58-65.

Mulder, V. L., de Bruin, S., Schaepman, M. E., and Mayr, T. R. (2011). The use of remote sensing in soil and terrain mapping - A review. Geoderma, 162(1-2), pp. 1-19.

Pennock D., Yates T. and Braidek J. (2006). Soil Sampling Designs. In Cater M. R. and Gregorich E. G., Soil Sampling and Methods of Analysis, $2^{\text {nd }}$ Edition, Tailor andFrancis Group, LLC.

Silva S. H. G., Owens P.R., Menezes M.D.D, Santos W. J. R., and Curi N. (2014). A Technique for Low Cost Soil Mapping and Validation Using Expert Knowledge on a Watershed in Minas Gerais, Brazil. Soil Sci. Soc. Am. J. 78, pp. 1310-1319.

Stanchi, S., Falsone, G., and Bonifacio, E. (2015). Soil aggregation, erodibility, and erosion rates in mountain soils (NW Alps, Italy). Solid Earth, 6(2), pp. 403-414.

Thomasson J. A., Sui R., Cox M. S., and Al-Rajehy A. (2013). Soil Reflectance Sensing for Determining Soil Properties in Precision Agriculture. Transactions of the ASAE, 44(6), pp. 14451453.

Van-Hall, R. L., Cammeraat, L. H., Keesstra, S. D., and Zorn, M. (2017). Impact of secondary vegetation succession on soil quality in a humid Mediterranean landscape. Catena, 149, pp. 836-843.

Viera, A. J., and Garrett, J. M. (2005). Interrater_agreement.Kappa_statistic, Family Medicine (May), 37(5) 360-3. http://www.twiki.org/p/pub/Main/Sigurdur RunarSaemund sson/ Interrater_agreement.Kappa_statistic.pdf

Yarbrough, L. D., Navulur, K., and Ravi, R. (n.d.). Presentation of the Kauth - Thomas transform for WorldView-2 reflectance data. Remote Sensing Letters, 5(2), pp. 37-41.

Yuksek, T., Gol, C., Yuksek, F., and Yuksel, E. E. (2009). The effects of land-use changes on soil properties: The conversion of alder coppice to tea plantations in the Humid Northern Blacksea Region. African Journal of Agricultural Research, 4(7), pp. 665-674.

Zribi, M., Baghdadi, N., and Nolin, M. (2011). Remote Sensing of Soil. Applied and Environmental Soil Science, Vol. 2011, Article ID 904561.

Cite this article as:

Eniolorunda N. B. and Jibrillah A. M., 2020. Application of Tasseled-Cap Transformation to Soil Textural Mapping of a Semi-Arid Environment: A Case of Usmanu Danfodiyo University Main Campus, Sokoto, Nigeria. Nigerian Journal of Environmental Sciences and Technology, 4(1), pp. 97-110. https://doi.org/10.36263/nijest.2020.01.0158 